\title{
Are sustainability-oriented investors different? Evidence from equity crowdfunding
}

\author{
Lars Hornuf $^{1,2,3}$ (D) Eliza Stenzhorn ${ }^{1} \cdot$ Tim Vintis $^{4}$
}

Accepted: 29 September 2021 / Published online: 17 October 2021

(c) The Author(s) 2021

\begin{abstract}
In this article, we examine how investor motives affect investment behavior in equity crowdfunding. In particular, we compare the investment behavior of sustainability-oriented with ordinary crowd investors on six leading equity crowdfunding platforms in Austria and Germany and investigate whether they suffer from a default shock that was recently identified by Dorfleitner et al. (2019). In general, we find evidence of a default shock in equity crowdfunding that occurs immediately after the event or if investors experience more than two insolvencies. Moreover, we find that sustainability-oriented investors pledge larger amounts of money and invest in more campaigns than ordinary crowd investors. The results also suggest that sustainability-oriented crowd investors care about non-financial returns, as they react more sensitively after experiencing a default in their equity crowdfunding portfolios, which indicates that they suffer beyond the pure financial loss. These findings contribute to recent literature on equity crowdfunding, socially responsible investing, and how individual investment motives and personal experiences affect investment decisions.
\end{abstract}

Keywords Equity crowdfunding - Individual investor behavior · Entrepreneurial finance · Social, ethical, and environmental investing $\cdot$ Socially responsible investing

JEL Classification G11 · G24 · K22 · M13

Lars Hornuf

hornuf@uni-bremen.de

http://www.hornuf.com

Eliza Stenzhorn

stenzhorn@uni-bremen.de

Tim Vintis

tvintis@uni-bremen.de

1 University of Bremen, Max-von-Laue-Straße 1, 28359 Bremen, Germany

2 Max Planck Institute for Innovation and Competition, Marstallplatz 1, 80539 Munich, Germany

3 CESifo Research Network, Poschingerstraße 5, 81679 Munich, Germany

4 University of Bremen, Enrique-Schmidt-Straße 1, 28359 Bremen, Germany 


\section{Introduction}

In this article, we examine the investment behavior of crowd investors on six leading equity crowdfunding platforms in Austria and Germany. We analyze whether the investment behavior of sustainability-oriented crowd investors differs from ordinary crowd investors. In particular, we test whether sustainability-oriented investors invest different amounts and/ or invest more frequently than ordinary crowd investors. The research most closely related to ours is the article by Vismara (2019), who investigates the motives of equity crowdfunding investors in the United Kingdom and shows that sustainability orientation does per se not affect funding success or the engagement of professional investors, but attracts more restricted investors. We extend on the previous research by investigating whether sustainability-oriented investors adapt their investment behavior differently from ordinary crowd investors after they experience a default in their portfolio. Such a default shock was recently identified by Dorfleitner et al. (2019) for the crowdlending market. It refers to investment behavior when lenders cease diversifying their portfolio after experiencing a default in their existing crowdlending portfolio. Before we investigate the potential differential effect of a default shock on sustainability-oriented and ordinary crowd investors, we test whether a default shock generally exists in equity crowdfunding.

Our analysis relates to various strands of literature. Our findings add to the emerging literature on equity crowdfunding, in which empirical research has primarily investigated the entrepreneurial side; i.e., how entrepreneurs who run a successful equity crowdfunding campaign behave. Seminal articles have assessed the magnitude, development, and geographic concentration of the equity crowdfunding market (Günther et al., 2018; Vulkan et al., 2016). Many scholars have analyzed the factors influencing funding success (Ahlers et al., 2015; Hornuf \& Schwienbacher, 2018a), studied the strategic choice of entrepreneurs between platforms (Coakley, 2021), and investigated the determinants of firm failure and follow-up funding after an equity crowdfunding campaign (Butticè et al., 2021; Hornuf et al., 2018b; Signori \& Vismara, 2018). In an early article, Agrawal et al. (2016) show that syndicates of well-informed lead investors trigger investments by less informed investors later on. More recently, Nguyen et al. (2019) show that investors in equity crowdfunding delay their investments to gain more information. Vismara (2016) provides evidence that the social capital of founders increases the chance of reaching the funding goal in an equity crowdfunding campaign. Johan and Zhang (2021) examine signals in equity crowdfunding and find that the importance of business characteristics to campaign success depends largely on the industry sector.

Empirical research has also focused on individual investment. Vismara (2018) shows that information cascades affect the investment process. Block et al. (2018a) provide evidence that updates by founders affect the investment dynamics during a campaign. Hornuf and Schwienbacher (2018b) find that the investment behavior and comments of other crowd investors affect investors' willingness to pledge money. Belleflamme et al. (2014) argue that building a community can be an important factor for the success of an equity crowdfunding campaign, indicating that investment motives in equity crowdfunding generally go beyond the pure financial return orientation of the investor. In a similar vein, Kleinert and Volkmann (2019) show that dialogues on equity crowdfunding platform discussion boards drive investments. Campaign creators therefore often appeal to emotional and non-financial factors to win over the crowd (Ramos, 2014). Research on the sustainability orientation of crowdfunding campaigns has mostly focused on reward-based crowdfunding (Calic \& Mosakowski, 2016; Hörisch, 2015). A noteworthy 
exception is Vismara (2019), who evidences that sustainability-oriented investors often follow a community logic, according to which they adhere to community values and believe in trust and reciprocity by the community.

Apart from the equity crowdfunding literature, our analysis adds to the literature on socially responsible investing (SRI) more generally. In line with Hudson's (2005) definition of an "ethical investor," we use the term "sustainability-oriented investors" to refer to crowd investors who base their investment decisions on their perceptions of whether the actions of the firms they invest in are sustainability oriented. Sustainability-oriented investors thus have similar motives to what has been termed in the literature as "socially responsible investors," "green investors," or "ethical investors" (e.g., Hudson, 2005; Nilsson, 2008). Theoretical models on SRI, for example, argue that investors make sustainability-oriented investments because of the societal impact of their investment decisions and because such investments are in line with their personal values (Beal \& Goyen, 1998; Social Investment Forum, 2008). Socially responsible investors also have a desire to facilitate social change (Beal et al., 2005). Campaigns on sustainability-oriented equity crowdfunding platforms often have a social, ethical, and/or environmental (SEE) orientation. Evaluating the investment behavior on these platforms enables us to provide new answers to classic research questions from the SRI literature. For example, does the investment behavior of sustainability-oriented investors differ from ordinary investors (Rosen et al., 1991; Williams, 2007)? How do non-financial return motives affect investment behavior (Jansson \& Biel, 2011; Owen \& Qian, 2008)?

Our research also relates to the literature on how personal experience affects investment decisions, which helps explain differences in portfolio compositions. Personal investment experience (Andersen et al., 2019; Chiang et al., 2011; Choi et al., 2009; Kaustia \& Knüpfer, 2008) and general economic circumstances (Knüpfer et al., 2017; Laudenbach et al., 2017; Malmendier \& Nagel, 2011) both affect individual investment decisions. Recently, Andersen et al. (2019) provided evidence that stock investors who suffered losses from defaults during the financial crises subsequently changed their risktaking behavior. Dorfleitner et al. (2019) find that even in comparatively good economic conditions, a default in a crowdlending portfolio influences investment behavior.

In summary, our analysis extends previous research in multiple ways. First, scholars have argued that understanding is still lacking on which specific factors influence the investment decisions of sustainability-oriented investors (Lagerkvist et al., 2020; Palacios-González \& Chamorro-Mera, 2018; Riedl \& Smeets, 2017; Wins \& Zwergel, 2016). We contribute to the understanding of sustainability-oriented investment decisions in equity crowdfunding, which has become a mainstream asset class during the last decade. Our study is unique in its focus on different investor types pledging their own money in real equity crowdfunding campaigns after an insolvency occurs in their portfolio. Second, although Dorfleitner et al. (2019) provide evidence for a default shock, this evidence is based on one subcategory of crowdfunding-crowdlendingand a single platform-Zencap. We analyze the default shock in a different market segment—equity crowdfunding — and investigate investors' behavior on six platform. Thus, our analysis provides significant external validity to prior findings. Third, Dorfleitner et al. (2019) investigate only investors who pledged money in company loans, whereas we differentiate between investors who made investments in regular start-up firms, real estate campaigns, and sustainability-oriented firms. Given that sustainability-oriented investors have SEE-related motives beyond the pure financial return motive, we expect them to be shocked more strongly if they experience a default in their equity crowdfunding portfolio. 
We find evidence that a default shock generally exists in equity crowdfunding immediately after the event or if investors experience more than two insolvencies. Furthermore, by differentiating between sustainability-oriented and ordinary crowd investors, we show that sustainability-oriented investors pledge higher amounts and invest in more campaigns. Finally, we show that sustainability-oriented investors react more negatively than ordinary crowd investors after an insolvency occurs, which we consider evidence that other investments motives beyond the pure financial return motive are at stake.

The rest of this article proceeds as follows: In Sect. 2, we outline the overall theoretical framework and develop hypotheses, and in Sect. 3, we describe our data and explain the method applied. In Sect. 4, we present our descriptive statistics and multivariate results. Section 5 provides an analytical discussion, and Sect. 6 summarizes our results, discusses limitations, and offers avenues for further research.

\section{Theoretical framework and hypotheses}

Equity crowdfunding is a new asset class for retail investors. Before equity crowdfunding platforms appeared as a new form of financial intermediation (Block et al., 2018b), the possibility to invest in start-up firms was available almost exclusively to business angels and venture capitalists. Retail investors have generally lacked the sophistication to draft investment contracts and to identify start-up firms that suited their portfolio needs. Today, equity crowdfunding investors can easily identify and invest in start-ups listed on equity crowdfunding platforms, which also provide boilerplate investment contracts for them.

Many retail investors have no experience with start-up finance and do not receive professional investment advice. Unlike banks, angel investors, or venture capitalists, crowd investors thus cannot be regarded as professional investors. They typically do not use credit risk models and sophisticated tools to control the risk-return relationship of their portfolios. For example, compared with professional investors, they are unlikely to run their own internal risk models for portfolio-steering decisions. Relative to their small investments, they would need to bear much higher transaction costs to evaluate the ideas of a start-up and the founder teams than angel investors and venture capitalists. From an economic standpoint, it is not feasible to spend multiple weeks on due diligence of a new venture, when only a comparatively small investment is at stake (Ahlers et al., 2015; Dorfleitner et al., 2019; Freear et al., 1994). Because crowd investors do not explicitly calculate expected default rates, they may be severely shocked by a default.

Dorfleitner et al. (2019) find that crowdlending investors suffer from a default shock that decreases their readiness to further diversify their portfolios. We conjecture that the default shock is likely to occur in equity crowdfunding as well because investors make risky investments with the expectation of a financial return. The default shock in equity crowdfunding might, however, be somewhat weaker. Unlike in crowdlending, in which investors receive annuity payments immediately after the loan campaign has been successfully funded, equity crowdfunding investors must wait several years until they receive their first repayments (Hornuf et al., 2018a). Thus, in equity crowdfunding investors rarely observe repayments, and their financial engagement might therefore be less salient after the funding period has ended. Consequently, it might require a strong loss or several insolvencies before investors show a default shock similar to the one Dorfleitner et al. (2019) observe for the crowdlending market. 
Moreover, Dorfleitner et al. (2019) observe that lenders not only stop investing after experiencing a default in their existing crowdlending portfolio but also consequently worsen the risk-return profile of their crowdlending portfolio. Our analysis is more modest, because we can only test whether equity crowdfunding investors change their investment behavior after an insolvency-that is, whether crowd investors pledge different amounts, change the likelihood of another investment, and/or change the number of subsequent investments. Because repayments occur irregularly and less frequently in equity crowdfunding (Hornuf et al., 2021), we cannot calculate the risk-adjusted return on capital (RAROC) of the equity crowdfunding portfolios in our sample. Consequently, we are also not able to determine whether the default shock leads to a deterioration of the risk-return profile of the portfolio. Nevertheless, before we examine whether sustainability-oriented investors differ in their response to an insolvency, we first need to examine whether a default shock exists in equity crowdfunding. We therefore pose the research question, Do equity crowdfunding investors suffer from a default shock?

Equity crowdfunding has enabled investors to fund firms from various industries and with very different business models. While early equity crowdfunding platforms have generally focused on start-up finance, the market has recently expanded to and specialized in sustainability-oriented as well as real estate campaigns (Hainz \& Hornuf, 2019). The firms behind sustainability-oriented crowdfunding campaigns have very different business models, but most of them focus on a clear SEE contribution. Nevertheless, they also aim to make a profit and promise a financial return to crowd investors. SEE ventures that do not intend to make a profit seek funding on donation-based crowdfunding platforms such as Betterplace, which is not part of this investigation. Thus, we explore whether investors on platforms that cater to sustainability-oriented campaigns behave differently from investors who invest on ordinary equity crowdfunding platforms.

On traditional financial markets, sustainability-oriented investors differ in how much money they pledge for sustainability-oriented investment products (Heeb et al., 2021). Mackenzie and Lewis (1999) find that some socially oriented investors might even dedicate their entire portfolio to socially oriented investment products. By contrast, Webley et al. (2001) evidence that ethical investors have only around one-fourth of ethical holdings in their portfolio. Thus, it is not clear how much and how frequently sustainability-oriented crowd investors invest in sustainability-oriented campaigns. However, as only a limited number of sustainability-oriented campaigns are usually available at a given point in time and secondary markets in which shares can be traded rarely exist in equity crowdfunding, ${ }^{1}$ sustainability-oriented crowd investors might need to invest larger amounts in a single sustainability-oriented issuer.

Calic and Mosakowski (2016) investigate technology and film/video campaigns on Kickstarter, on which backers receive perks or pre-purchase a product still in the process of development, and find that the sustainability orientation of a campaign positively affects funding success. Possible explanations for why sustainability-oriented campaigns in reward-based crowdfunding are more successful could be that either backers pledge larger amounts or these campaigns simply attract more backers. While Calic and Mosakowski do not elaborate on these questions, they show that the success of sustainability-oriented campaigns on Kickstarter is at least partially mediated by the creativity and third-party endorsements of the campaign. Siemroth and Hornuf (2021)

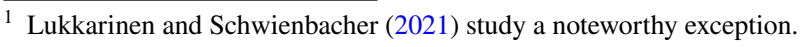


conducted a decision experiment among equity crowdfunding investors, in which investors chose between a higher return and environmental impact. They find that $60 \%$ of investors chose environmental impact at the expense of a higher return for sufficiently large impact, while $25 \%$ chose the higher return independent of impact. For campaigns on Indiegogo, Hörisch (2015) finds no evidence that the environmental orientation of a campaign has an effect on funding success. Likewise, Vismara (2019) investigates the platforms Crowdcube and Seedrs and shows that sustainability orientation does not affect funding success. Cholakova and Clarysse (2015) analyze data from the largest Dutch equity crowdfunding platform Symbid and find no evidence that non-financial motives play a role when investors pledge their money. While the evidence on funding success is mixed, no previous study has shown that a sustainability orientation makes funding success less likely. In line with Calic and Mosakowski's (2016) findings, we therefore conjecture that sustainability-oriented investors pledge larger amounts of money and invest more frequently.

Hypothesis 1 In equity crowdfunding, sustainability-oriented investors invest larger amounts of money and make more investments.

In addition, we explore the investment behavior of sustainability-oriented investors after they experience an insolvency. The research question that arises from Dorfleitner et al. (2019) is whether socially oriented crowd investors react more severely to an insolvency. Pasewark and Riley (2010) provide experimental evidence that the interaction between investment returns and their personal values affects the investment decisions of sustainability-oriented investors. This finding is also in line with Lewis and Mackenzie's (2000a) and Webley et al.'s (2001) argument that investors reduce their sustainability-oriented holdings after they discover that these investments yield lower returns. Mackenzie and Lewis (1999) show that while investors would not reduce their sustainability-oriented holdings if returns were two percentage points lower, for returns five percentage points lower, more than one-third of these investors would reduce their sustainability-oriented holdings. It is reasonable to assume that in the domain of equity crowdfunding, recovery rates after an insolvency are virtually zero because of the almost non-existent net asset values of a start-up firm and the subordination specified in many funding contracts (Hainz et al., 2019; Hornuf et al., 2021). Thus, insolvency should have a strong impact on crowd investors. Sustainability-oriented investors might respond even more severely than ordinary crowd investors to an insolvency for two reasons.

First, Levitt and List (2007) argue that the utility function of economic agents is not only determined by profit motives, but also by the presence of moral and ethical considerations. Sustainability-oriented investors in particular are likely to be both "profit-oriented" and "pro-social" (Beal et al., 2005; Bollen, 2007; Nilsson, 2008). Theoretical and empirical research shows that profit calculations and pro-social attitudes actually determine investors' willingness to pledge their money in SRI funds (Beal et al., 2005; Cullis et al., 1992; Heeb et al., 2021; Lewis \& Webley, 1994; Nilsson, 2008; Pasewark \& Riley, 2010; Riedl \& Smeets, 2017; Wins \& Zwergel, 2016). Building on these findings, Marsat et al. (2018) postulate that an investor's utility function depends on three attributes of an asset that are supposed to be independent: the expected financial return $(R)$, expected financial risk $(\theta)$, and expected ethics $(E)$ as a proxy for the level of sustainable responsibility. If $U$ denotes an investor's utility and $u$ an investor's utility function, it follows that: 


$$
U=u(R, \theta, E) \text { with } \frac{\partial U}{\partial R}>0 ; \frac{\partial U}{\partial \theta}<0 \text { and } \frac{\partial U}{\partial E}>0 .
$$

Moreover, prospect theory suggests that economic agents distinguish financial losses and gains. The value function that has been proposed by Kahnemann and Tversky (1979) is convex for losses, which implies that the marginal value of losses decreases with their magnitude. Hence, if expected financial returns and ethics of an asset are indeed independent, sustainability-oriented investors suffer more, because for them $\frac{\partial U}{\partial E}$ is by definition larger than for ordinary crowd investors (Beal et al., 2005). Put differently, an insolvency violates not only sustainability-oriented investors' financial return expectations but also their nonfinancial expectations related to SEE motives.

Moreover, consumers are, for example, more likely to become active on a social issue if they believe that their behavior helps resolve the issue at stake, a situation often referred to as perceived consumer effectiveness (Berger \& Corbin, 1992; Ellen et al., 1991; Straughan \& Roberts, 1999). Nilsson (2008, p. 311) argues that perceived consumer effectiveness translates into an investment context, stating that "people who do not believe that their individual investments in SRI profiled funds can help towards solving SEE issues will not be likely to invest in SRI mutual funds even though they agree with the social initiative." In an equity crowdfunding context, the SEE issues will be resolved by the firm that applied for funding on the platform. If a sustainability-oriented firm fails, a personal investment can no longer help solve the SEE problem in question, and next to the financial loss, the insolvency hurts another major investment motive. ${ }^{2}$

Second, evidence shows that SRI holdings perform similar on a risk-adjusted basis as compared with ordinary investments (Rivoli, 2003; Statman, 2000). However, what often matters to investors is not the objective risk and performance of an investment but the perceived risk and performance of a sustainability-oriented investment (Nilsson, 2008). The perception of low risk and good financial performance can increase the likelihood of an investment in the first place. Gevlin (2007) and Nilsson (2008) find that the majority of sustainability-oriented investors expect their investments to be less risky and to yield higher returns than other investments. Byrne (2005) and MacGregor et al. (1999) argue that the possible consequences of poor investment decisions influence the subjective perception of risk in mutual funds. Consequently, if sustainability-oriented crowd investors perceive their investments initially as less risky and if an insolvency then increases their perception of risk, an insolvency could have a more detrimental effect on their propensity to invest.

It can be argued that investors in sustainability-oriented equity crowdfunding should expect a return based on the market risk exposure of their investment (Hudson, 2005). An insolvency in a sustainability-oriented crowd investor's portfolio might, however, also entail another objective risk, because the smaller number of issuers in equity crowdfunding makes it more difficult to diversify firm-specific risks. As noted previously, this is because only a few equity crowdfunding campaigns seek funds at a certain point in time, as there is no secondary market and shares are not traded after the funding period has ended. Moreover, given that not all platforms have a sustainability orientation, the number of sustainability-oriented campaigns is even smaller. If the number of sustainability-oriented issuers is too small or these firms are too similar, investors lack opportunities to diversify

\footnotetext{
${ }^{2}$ By contrast, several studies argue that even if returns on investments are expected to be lower, SRI still generates personal emotional benefits (Beal et al., 2005), or investors' ethical motivations induce socially responsible fund loyalty due to a moral factor (Peifer, 2014; Sparkes, 2001).
} 
campaign-specific risk and thus confront higher costs to hedge otherwise diversifiable firm-specific risk (Hudson, 2005). Thus, after a portfolio firm fails, it might be too expensive for an investor to hedge the firm-specific risk and stay in the market.

Moreover, sustainability-oriented investors often prefer passive investments, in which a fund manager actively picks appropriate SEE stocks for them and filters out inappropriate stocks (Lewis \& Mackenzie, 2000b). Some investors might, however, believe that professional investment activities and government action are not enough and that they have a responsibility to take financial actions themselves to improve society (Sandberg, 2018). If sustainability-oriented crowd investors dare to select their own investment targets that later result in an insolvency, they might more easily blame themselves for the realized loss and consequently stop investing or move from equity crowdfunding to more passive forms of SEE investments. Taking these arguments together, we expect sustainability-oriented investors to be shocked more severely after an insolvency occurs.

Hypothesis 2 In equity crowdfunding, sustainability-oriented investors are more severely affected by a default shock than ordinary crowd investors.

\section{Data and method}

\subsection{Data}

To test our research question and hypotheses, we analyze investment decisions of crowd investors from November 6, 2011, to June 20, 2018, at six different equity crowdfunding platforms: Bettervest, Companisto, Green Rocket, Home Rocket, Innovestment, and Lion Rocket. These platforms were selected, because they are either the market leaders (Companisto for start-up crowdfunding, Bettervest for sustainability-oriented crowdfunding), have entered the market early (Innovestment), or allowed us to identify investors across platforms (Green Rocket, Home Rocket, and Lion Rocket). Bettervest and Green Rocket only offer investment opportunities in sustainability-oriented firms. Bettervest defines its motto as follows: "Bettervest is an online platform for impact investments. Finance sustainable projects that benefit both people and planet." ${ }^{* 3}$ Green Rocket states: "GREEN ROCKET is the first equity crowdfunding platform that specializes in sustainable companies in the fields of energy, environment, mobility and health." "Home Rocket offers only real estate investments. Companisto, Innovestment, and Lion Rocket focus on equity crowdfunding for start-ups. All platforms are from Germany except for Lion Rocket, which is an Austrian platform. Table 1 shows the distribution of investments, investors, and campaigns for each platform. For the platforms Green Rocket, Home Rocket, and Lion Rocket-which belong to the same corporate group-we are able to identify whether investors are active on more than one of the three equity crowdfunding platforms. Because Bettervest, Companisto, and Innovestment have a platform-specific investor ID, we cannot identify whether investors engaged across platforms.

\footnotetext{
3 Source: https://www.bettervest.com/en/, last accessed 27 June 2021.

4 Translation by the authors. Original text on corporate website: "GREEN ROCKET ist die erste Crowdinvesting-Plattform, die sich auf nachhaltige Unternehmen in den Bereichen Energie, Umwelt, Mobilität und Gesundheit spezialisiert." Source: https://www.greenrocket.de, last accessed 27 June 2021.
} 
Table 1 Sample

\begin{tabular}{llcll}
\hline Platform name & Platform type & Investments & Investors & Campaigns \\
\hline Bettervest & Sustainability-oriented & 13,660 & 2781 & 70 \\
Companisto & Equity & 49,556 & 17,168 & 86 \\
Green rocket & Sustainability-oriented & 9537 & 4298 & 49 \\
Home rocket & Real estate & 7281 & 2100 & 22 \\
Innovestment & Equity & 1628 & 559 & 43 \\
Lion rocket & Equity & 1376 & 881 & 9 \\
Total & & 83,038 & 27,787 & 279 \\
\hline
\end{tabular}

The table shows the distribution of investments, investors, and campaigns over the six equity crowdfunding platforms

Table 2 Frequencies of campaigns, investments, and insolvencies

\begin{tabular}{llll}
\hline & Equity & Sustainability-oriented & Real estate \\
\hline Campaigns & & & \\
Absolute frequency & 138 & 119 & 22 \\
Relative frequency & $49.46 \%$ & $42.65 \%$ & $7.89 \%$ \\
Investments & & & 7.281 \\
Absolute frequency & 42.560 & 23.197 & $9.97 \%$ \\
Relative frequency & $58.27 \%$ & $31.76 \%$ & \\
Insolvencies & & & 0 \\
Absolute frequency & 28 & 3 & $0.00 \%$ \\
Relative frequency & $43.51 \%$ & $4.90 \%$ & \\
\hline
\end{tabular}

The table presents the absolute and relative frequencies of campaigns, investments, and insolvencies of the equity crowdfunding campaigns, separated in equity, sustainability-oriented, and real estate campaigns

For 7279 investors on the three Rocket platforms, we find that 1546 were active on more than one of the platforms, which reduces the number of unique investors on these platforms to 5733 investors. For the remaining platforms, we were not able to make this correction. Our unit of observation for the multivariate analysis is whether investors made an investment or not. Investors are included in the analysis as soon as they made their first investment. In total, our sample contains $1,249,271$ investment decisions from $26,241^{5}$ investors who decided to invest 83,038 times in 279 different equity crowdfunding campaigns. Table 2 shows the percentage of firms on each platform that went into insolvency, were liquidated, or were dissolved as of the end of our observation period. Table 3 reports descriptive statistics, and Table 4 provides variable descriptions.

Empirical research has frequently classified investors as either "ethical" or "conventional" investors, depending on whether they invested in at least one socially responsible fund (Beal et al., 2005; Lewis \& Mackenzie, 2000a, b; McLachlan \& Gardner, 2004;

\footnotetext{
5 Because we could not identify investors from Companisto by an investor ID, similar to Hornuf et al. (2020), we assume that the name and location combination is a valid proxy for identifying a unique investor. We exclude investments by users with the 20 most popular German names, because it is likely that there is more than one investor with a name such as "Michael" who lives in a big city such as Munich.
} 
Table 3 Descriptive statistics

\begin{tabular}{llllll}
\hline Variable & $\mathrm{N}$ & Mean & SD & Min & Max \\
\hline AltGlobal & $1,249,271$ & 32.792 & 11.137 & 2 & 71 \\
AltPlatform & $1,249,271$ & 4.309 & 2.137 & 0 & 11 \\
AmountLost & 26,241 & 60.521 & 612.551 & 0 & 50,000 \\
ExpInsol & 26,241 & 0.161 & 0.368 & 0 & 1 \\
InvPast & 26,241 & 2.939 & 4.983 & 1 & 153 \\
NewInvAmount & $1,249,271$ & 44.228 & 737.940 & 0 & 283,000 \\
NewInvDummy & $1,249,271$ & 0.049 & 0.216 & 0 & 1 \\
NumInsol & 26,241 & 0.167 & 0.615 & 0 & 10 \\
ShareCapLost & $1,249,271$ & 0.028 & 0.148 & 0 & 1 \\
Sustainability & $1,249,271$ & 0.206 & 0.404 & 0 & 1 \\
ToP & $1,249,271$ & 4.942 & 4.539 & 0 & 19.930 \\
\hline
\end{tabular}

The table shows the descriptive statistics of investment decisions and investors. Variables are defined in Table 4

Williams, 2007). We classify investors as sustainability-oriented investors if they invest in campaigns on Green Rocket or Bettervest, which specialize in funding SEE business ideas. To be clear, we do not assume that investors on these two platforms are purely driven by SEE motives. However, because sustainability-oriented crowd investors need to actively search for and select an equity crowdfunding campaign without professional guidance, we believe that investors who actively select SEE campaigns reveal their SEE preferences and consequently treat them as more sustainability oriented than investors on ordinary equity crowdfunding platforms. This is also in line with literature on SRI, which argues that investors should be categorized on a continuum ranging from a purely ethical orientation to a strictly financial orientation in terms of the extent to which personal values influence their investment decision (Hummels \& Timmer, 2004). Moreover, investors who direct larger parts of their overall portfolio in socially responsible investments should have stronger prosocial attitudes than investors who invest less in these projects (Nilsson, 2008). Thus, we consider investors on Green Rocket and Bettervest more sustainability oriented than ordinary crowd investors.

\subsection{Sampling}

In our dataset, 4559 investors experienced at least one insolvency. Investors who have experienced a default could refrain from investing further for multiple reasons. For example, the longer investors are investing in equity crowdfunding, the more likely it is that they will experience a default. At the same time, the longer investors are active in this new asset class, the more investments have been offered to them and the less likely the next start-ups will be included in the portfolio. To address this selection problem, we conduct Euclidean distance matching (King \& Nielsen, 2019). More precisely, we create an artificial control group with investors who experienced no insolvency but have similar characteristics to the 4559 investors who experienced at least one insolvency. This procedure results in less biased regression coefficients and more robust results. We use the k-nearest-neighbors (KNN) method to create our artificial control group. With the KNN sampling, we respectively identify three investors who are most similar to an investor who experienced an 
Table 4 Definition of variables

Dependent variables

NewInvAmount

NewInvDummy

\#NewInv

Explanatory variables

ExpInsol

NumInsol

ShareCapitalLost

Sustainability

ExpInsol30

ExpInsol_Lag $1-5$ days

ExpInsol_Lag $6-10$ days

ExpInsol_Lag $11-15$ days

Control variables

AltPlatform

AltGlobal

AmountLost

InvPast

ToP
Amount of new investments during the focal campaign in EUR

Dummy variable indicating whether the investor carried out at least one new investment during the focal campaign

Number of new investments an investor carried out during the focal campaign

Dummy variable indicating whether the investor has already experienced at least one insolvency at the beginning of the focal campaign

Number of insolvencies an investor has experienced at the beginning of the focal campaign

Percentage of capital an investor lost from the focal insolvency relative to its overall portfolio amount on the sampled crowdfunding platforms

Dummy variable indicating whether the focal campaign is run by a sustainabilityoriented firm

Dummy variable indicating whether the investor had experienced at least one insolvency 30 days before the beginning of the focal campaign

Dummy variable indicating whether the investor had experienced at least one insolvency one to five days before the beginning of the focal campaign

Dummy variable indicating whether the investor had experienced at least one insolvency six to ten days before the beginning of the focal campaign

Dummy variable indicating whether the investor had experienced at least one insolvency 11-15 days before the beginning of the focal campaign

Number of alternative, active campaigns on the equity crowdfunding platform on which the investor is active at the beginning of the focal campaign

Number of alternative, active campaigns in the whole German equity crowdfunding market at the beginning of the focal campaign

Amount lost by an investor because of an insolvency in EUR

Number of investments an investor has already made in the past before the beginning of the focal campaign

Time on the platform, calculated as the number of days between the first investment ever made on the equity crowdfunding platform by the investor and the beginning of the focal campaign (measured over 100 days)

Table reports the definitions of variables

insolvency. We ensure that every observation has at least one individual neighbor, which is not the nearest neighbor of any other observation. For the KNN matching, we use several variables to match investors.

We match investors on the platform, because the decision on which equity crowdfunding platform an investor makes pledges already contains information about the motives of the investor, given that equity crowdfunding platforms focus on different kinds of firms. We also match investors on experience in equity crowdfunding, measured as the time since the first investment was made. Investors with more experience in equity crowdfunding could behave differently than less experienced investors. For example, experienced investors could screen firms more carefully or focus on different aspects of the firms than an investor with less experience. Furthermore, if an investor's first investment was in an equity crowdfunding firm a long time ago, it is more likely that he or she already had returns on his or her investment, which could influence investment decisions in the future. As an 


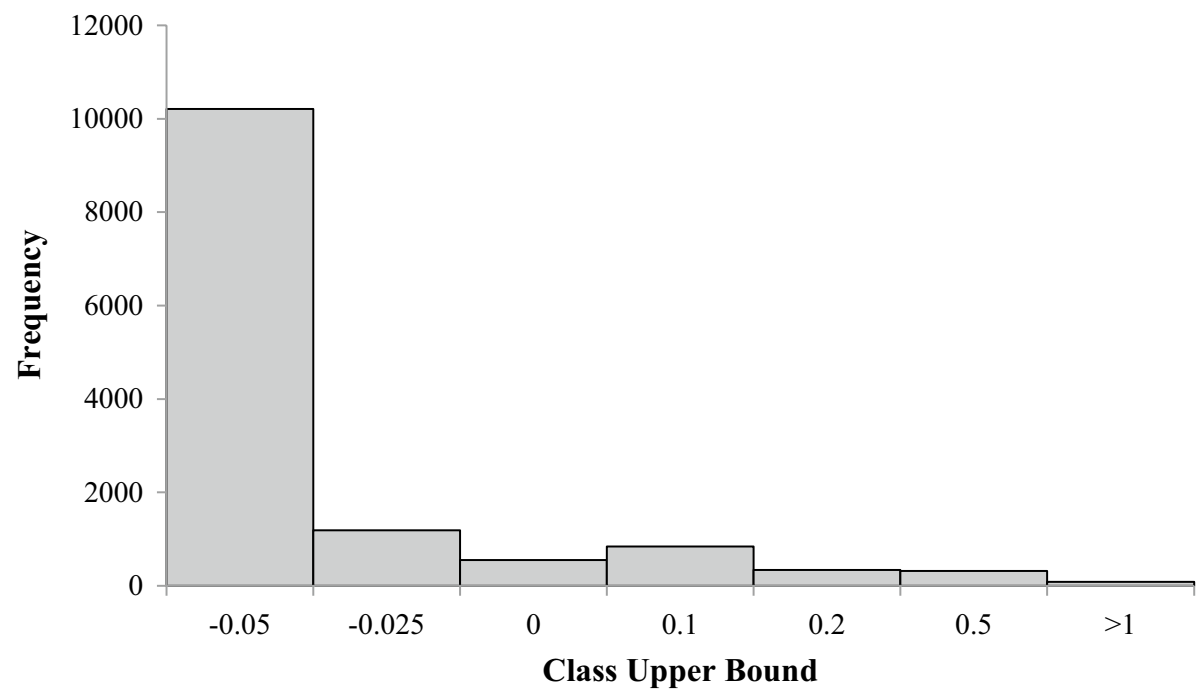

Fig. 1 Euclidean distances from KNN matching. Standardized Euclidean distances from KNN matching of investors (with $\mathrm{k}=3$ chosen nearest neighbors) who experienced at least one insolvency (treatment group) with similar investors who experienced no insolvency (artificial control group)

alternative measure of investment experience, we match investors on the number of investments an investor made in equity crowdfunding campaigns. This variable also captures the propensity to diversify the equity crowdfunding portfolio. Finally, we match investors on total investment amount, which serves as a proxy for the financial sophistication of the investor. Investors with high income or wealth generally have more money available for investments and will more likely also invest higher amounts of money in equity crowdfunding firms. Although it would be preferable to use the income or overall investment portfolio of an investor, given that such data are not available to us, we consider the total investment amount in equity crowdfunding campaigns an approximation of these variables.

Figure 1 shows the Euclidean distances for matched investors, indicating the quality of our matching procedure. Euclidean distances are calculated in a multi-dimensional space based on the values of the variables used in the KNN matching. We standardize the distances to judge whether the distance is small or large between investors. In total, $99.4 \%$ of all distances are between -2 and +2 standard deviations and $98.9 \%$ between -1 and +1 standard deviations. These results indicate that our matching procedure worked as intended, and for investors who experienced an insolvency, we found similar investors who did not experience an insolvency. Our matched sample contains data on 9400 unique investors, 4559 of whom experienced at least one insolvency; 5017 investors did not experience any insolvency. These investors confronted 496,148 investment decisions.

\subsection{Regression model}

We use three different dependent variables to analyze investment decisions that are captured by the term InvDec. Our first dependent variable is NewInvAmount, which measures the amount of capital invested by investor $i$ in the focal campaign $j$ on platform $k$, and run ordinary least squares (OLS) regressions. In addition, we use NewInvDummy as a 
dependent variable, which is a dummy variable equal to 1 if investor $i$ decides to invest in campaign $j$ on platform $k$. Given that our dependent variable is dichotomous and measures whether an investor makes an investment or not, we run a logit regression model to identify which factors drive the investment decision. A positive regression coefficient indicates a higher probability to invest in the respective campaign. Finally, we use \#NewInv as a dependent variable, which is the number of new investments by investor $i$ in the focal campaign $j$ on platform $k$, and run a negative binomial model. For logit regressions, we report average marginal effects, and for negative binomial models, we report incidence rate ratios. The latter can conveniently be interpreted as multiplicative effects. We specify the baseline regression model as follows:

$$
\text { InvDec }_{i, j, k}=\beta_{0}+\beta_{1} \text { ExpInsol }_{i}+\beta_{2} \text { NumInsol }_{i}+\beta_{3} \text { Sustainability }_{j}+\beta_{4} \text { InvPast }_{i}+\beta_{5} \text { ToP }_{i}+\epsilon_{i},
$$

where ExpInsol, our variable of interest, is a dummy variable equal to 1 if the investor had experienced at least one insolvency and NumInsol is the total number of experienced insolvencies by the investor. The latter variable captures whether the marginal propensity to invest changes after the investor experienced more than one insolvency in the portfolio. Alternatively, the amount lost from an insolvency could affect investment decisions more strongly. In robustness tests, we therefore include ShareCapitalLost, which is the percentage of capital invested in equity crowdfunding the investor lost from an insolvency, and AmountLost, which is the amount of capital lost by an investor. The dummy variable Sustainability, our third variable of interest, equals 1 if the campaign is run by a sustainability-oriented firm and 0 otherwise. The variable InvPast is the number of investments an investor has made before the focal investment decision; it captures the equity crowdfunding experience of an investor. Finally, we control for the time the investor has been active on the platform $(T o P)$, measured as days between the first investment on the platform and the start of the focal campaign.

\section{Results}

\subsection{Regression results}

We first investigate our research question. Table 5 shows the results of our baseline regression. For all models, we find that ExpInsol is significantly positively associated with our dependent variables. If an investor in our equity crowdfunding sample experiences an insolvency in his or her portfolio, it is more likely that he or she makes another investment. Moreover, investors who experience an insolvency also invest larger amounts of money and make more investments in the focal equity crowdfunding campaign. This finding is robust and provides a negative answer to our research question, which asks whether investors in equity crowdfunding suffer from a default shock. However, the negative coefficients of NumInsol indicate that the positive default shock fades away the more insolvencies the investor has experienced. ${ }^{6}$ An additional insolvency in the portfolio reduces the probability of an investor to invest in a new campaign by $3.2 \%$. Given that the probability of making a new investment is $7.1 \%$ on average, the economic significance of this variable is large

\footnotetext{
${ }^{6}$ We repeat the regression analysis with models that contain either ExpInsol or NumInsol, to ensure that our results are not affected by multicollinearity. The results remain robust and are available on request.
} 
Table 5 Regression results of baseline specification

\begin{tabular}{llll}
\hline Dependent variable & $(1)$ & $(2)$ & $(3)$ \\
& NewInvAmount & NewInvDummy & \#NewInv \\
\hline ExpInsol & $57.4821 * * *$ & $0.0497 * * *$ & $2.0285^{* * * *}$ \\
& $(5.7675)$ & $(0.1032)$ & $(0.0413)$ \\
NumInsol & $-62.5404 * * *$ & $-0.0322 * * *$ & $0.5417 * * *$ \\
& $(4.8492)$ & $(0.0791)$ & $(0.0299)$ \\
Sustainability & 18.9120 & $0.0280^{* * *}$ & $2.2253^{* * *}$ \\
& $(3.1624)$ & $(0.0304)$ & $(0.0092)$ \\
InvPast & $11.8736 * * *$ & $0.0063 * * *$ & $1.0722 * * *$ \\
& $(0.6437)$ & $(0.0069)$ & $(0.0007)$ \\
ToP $\times 10^{-2}$ & $-6.6871 * * *$ & $-0.0072 * * *$ & $0.8663 * * *$ \\
Constant & $(0.3275)$ & $(0.0061)$ & $(0.0011)$ \\
Time FE & $63.6191 * * *$ & & $1.5698^{* * *}$ \\
$\mathrm{~N}$ & $(5.9077)$ & & $(0.0371)$ \\
Pseudo-/Adj. $\mathrm{R}^{2}$ & Yes & Yes & Yes \\
$P(\mathrm{Y}=1)$ & 496,148 & 496,148 & 496,148 \\
\hline
\end{tabular}

This table shows the results of the baseline regressions for the sampled dataset with $\mathrm{k}=3$ chosen nearest neighbors. The dependent variable is the investor's newly invested amount (OLS, specification (1)), a dummy variable indicating whether the investor carried out at least one new investment in a certain campaign (logit, specification (2)), and the number of investments an investor newly undertook (negative binomial, specification (3)). Variables are defined in Table 1. Standard errors are clustered at the investor level and reported in parentheses. Coefficients reported are average marginal effects for the logit model and incidence rate ratios for the negative binomial model. Significance levels: $*<0.10, * *<0.05$, and $* * *<0.01$

and indicates that three insolvencies are enough to confirm the default shock of Dorfleitner et al. (2019) in equity crowdfunding. With every additional insolvency in the portfolio, the average amount invested is reduced by 62.54 EUR and the number of additional investments by $45.8 \%$.

For Hypothesis 1, which states that sustainability-oriented investors in equity crowdfunding invest larger amounts of money and make more investments, we find that the variable Sustainability is not significant in the OLS regression (Table 5). However, it is significantly positive in the logit regression, which provides evidence that sustainability-oriented investors are generally more likely to invest in the focal campaign. Moreover, in the negative binominal regression, we find that sustainability-oriented investors make on average more than twice as many investments than ordinary crowd investors, which is in line with Hypothesis 1. Regarding the control variables, we find that InvPast, which measures the investment experience in equity crowdfunding, has a robust and significantly positive effect on our dependent variables, while the time investors are registered on the platform (ToP) has a robust and significantly negative effect in all three models.

In Table 6, we add the interaction term ExpInsol $\times$ Sustainability to investigate Hypothesis 2, which states that there is a differential effect for sustainability-oriented investors with regard to the default shock. Our regression results reveal that after experiencing an insolvency, investors on sustainability-oriented platforms invest significantly lower amounts and have a significantly lower probability to invest. If the insolvency occurred on a sustainability-oriented platform rather than an ordinary equity crowdfunding platform, the subsequent average amount invested is 21.25 EUR lower, and the likelihood of an 
Table 6 Regression result including ExpInsol $\times$ Sustainability

\begin{tabular}{|c|c|c|c|}
\hline Dependent variable & $\begin{array}{l}\text { (1) } \\
\text { NewInvAmount }\end{array}$ & $\begin{array}{l}\text { (2) } \\
\text { NewInvDummy }\end{array}$ & $\begin{array}{l}\text { (3) } \\
\text { \#NewInv }\end{array}$ \\
\hline ExpInsol & $\begin{array}{l}59.2288 * * * \\
(5.9242)\end{array}$ & $\begin{array}{l}0.0521 * * * \\
(0.0867)\end{array}$ & $\begin{array}{l}2.0073 * * * \\
(0.0434)\end{array}$ \\
\hline NumInsol & $\begin{array}{l}-62.9459 * * * \\
(4.8670)\end{array}$ & $\begin{array}{l}-0.0325^{* * * *} \\
(0.0800)\end{array}$ & $\begin{array}{l}0.5425 * * * \\
(0.0301)\end{array}$ \\
\hline Sustainability & $\begin{array}{l}19.8467 * * * \\
(3.2432)\end{array}$ & $\begin{array}{l}0.0272 * * * \\
(0.0306)\end{array}$ & $\begin{array}{l}2.1990 * * * \\
(0.0094)\end{array}$ \\
\hline ExpInsol $\times$ Sustainability & $\begin{array}{l}-21.2454 * * * \\
(8.0246)\end{array}$ & $\begin{array}{l}-0.0064 * * \\
(0.1461)\end{array}$ & $\begin{array}{l}1.0659 * \\
(0.0361)\end{array}$ \\
\hline InvPast & $\begin{array}{l}11.8751 \text { *** } \\
(0.6437)\end{array}$ & $\begin{array}{l}0.0063 * * * \\
(0.0070)\end{array}$ & $\begin{array}{l}1.0722 * * * \\
(0.0007)\end{array}$ \\
\hline $\mathrm{ToP} \times 10^{-2}$ & $\begin{array}{l}-6.6759 * * * \\
(0.3279)\end{array}$ & $\begin{array}{l}-0.0073 * * * \\
(0.0061)\end{array}$ & $\begin{array}{l}0.8612 * * * \\
(0.0011)\end{array}$ \\
\hline Constant & $\begin{array}{l}63.1016 * * * \\
(5.9283)\end{array}$ & & $\begin{array}{l}1.5734 * * * \\
(0.0372)\end{array}$ \\
\hline Time FE & Yes & Yes & Yes \\
\hline $\mathrm{N}$ & 496,148 & 496,148 & 496,148 \\
\hline Pseudo-/Adj. R ${ }^{2}$ & 0.0122 & 0.1726 & 0.3257 \\
\hline$P(\mathrm{Y}=1)$ & & $7.11 \%$ & \\
\hline
\end{tabular}

This table shows the results of the baseline regressions for the sampled dataset with $\mathrm{k}=3$ chosen nearest neighbors. We add an interaction term ExpInsol $\times$ Sustainability to check whether the reaction to experienced insolvencies changes if the investor is a sustainability-oriented investor rather than a start-up investor. The dependent variable is the investor's newly invested amount (OLS, specification (1)), a dummy variable indicating whether the investor carried out at least one new investment in a certain campaign (logit, specification (2)), and the number of investments an investor newly undertook (negative binomial, specification (3)). Variables are defined in Table 1. Standard errors are clustered at the investor level and reported in parentheses. Coefficients reported are average marginal effects for the logit model and incidence rate ratios for the negative binomial model. Significance levels: $*<0.10, * *<0.05$, and $* * *<0.01$

additional investments is reduced by $0.6 \%$. This result is in line with Hypothesis 2 and can be attributed to the violation of a major investment motive of sustainability-oriented crowd investors other than the financial loss.

An alternative to the explanation that a default shock affects sustainability-oriented investors more severely could be that they lose larger amounts relative to their overall crowdfunding portfolio as a result of an insolvency. In a next step, we therefore test whether the relative amount that was lost because of an insolvency, measured by the variable ShareCapitalLost, affects the default shock. The results from the OLS and negative binomial regressions in Tables 7 and 8 show that investors who lost relatively more money from an insolvency generally tend to invest larger amounts but are more likely to reduce the number of investments. The coefficient from the OLS regression indicates that the average amount invested increases by 68.08 EUR if the amount lost relative to the invested capital increases by 1 percentage point. Furthermore, we find that the number of additional investments decreases by $35.1 \%$ if the amount lost relative to the invested capital increases by 1 percentage point. Importantly, the coefficient of NumInsol remains negative, so the default shock re-occurs if investors experience multiple insolvencies. Finally, the interaction term ShareCapitalLostxSustainability indicates that sustainability-oriented investors tend to invest smaller amounts and are less likely to invest than other investors if the amount lost 
Table 7 Regression results including ShareCapitalLost

\begin{tabular}{llll}
\hline Dependent variable & $(1)$ & $(2)$ & $(3)$ \\
& NewInvAmount & NewInvDummy & \#NewInv \\
\hline ShareCapitalLost & $68.0780^{* * *}$ & $0.0064 *$ & $0.6486 * * *$ \\
& $(5.9143)$ & $(0.0791)$ & $(0.0443)$ \\
NumInsol & $-50.6127 * * *$ & $-0.0194 * * *$ & $0.7177 * * *$ \\
& $(4.0271)$ & $(0.0455)$ & $(0.0165)$ \\
Sustainability & $17.7153 * * *$ & $0.0266^{* * *}$ & $2.1609 * * *$ \\
& $(3.1681)$ & $(0.0304)$ & $(0.0093)$ \\
InvPast & $12.2708^{* * *}$ & $0.0062 * * *$ & $1.0674 * * *$ \\
& $(0.7021)$ & $(0.0072)$ & $(0.0008)$ \\
ToP $\times 10^{-2}$ & $-6.4313 * * *$ & $-0.0068 * * *$ & $0.8732 * * *$ \\
& $(0.3427)$ & $(0.0063)$ & $(0.0011)$ \\
Constant & $68.0780^{* * *}$ & & $1.5656 * * *$ \\
Time FE & $(5.9143)$ & & $(0.0428)$ \\
$\mathrm{N}$ & Yes & Yes & Yes \\
Pseudo-/Adj. $\mathrm{R}^{2}$ & 496,148 & 496,148 & 496,148 \\
$P(\mathrm{Y}=1)$ & 0.0122 & 0.1692 & 0.3226 \\
\hline
\end{tabular}

This table shows the results of the baseline regressions for the sampled dataset with $k=3$ chosen nearest neighbors. We use the percentage of invested capital, which the investor lost from insolvencies, instead of the experienced insolvency dummy in this setting. The dependent variable is the investor's newly invested amount (OLS, specification (1)), a dummy variable indicating whether the investor carried out at least one new investment in a certain campaign (logit, specification (2)), and the number of investments an investor newly undertook (negative binomial, specification (3)). Variables are defined in Table 1. Standard errors are clustered at the investor level and reported in parentheses. Coefficients reported are average marginal effects for the logit model and incidence rate ratios for the negative binomial model. Significance levels: $*<0.10$, $* *<0.05$, and $* * *<0.01$

relative to their crowdfunding portfolio is larger. With regard to Hypothesis 2, this provides additional evidence that, in particular, sustainability-oriented investors suffer from a default shock.

\subsection{Lagged effects of an insolvency}

In a next step, we test whether the default shock is more pronounced shortly after the investor experienced an insolvency and whether it fades away after a certain point. In Table 9, we include three lags of the variable ExpInsol in our regression model. The lags contain a period of one to five days, six to ten days, and 11-15 days, respectively, after the insolvency. Estimation of the one-to-five-day lag is not feasible in the logit specification, because NewInvDummy has no variance when ExpInsol_Lag ${ }_{5-10}$ is equal to 1 . In other words, no investor who experienced an insolvency made at least one new investment five days after the event. All three models show ascending coefficients of the lagged variables. The coefficients of the one-to-five-day window in the OLS and the six-to-ten-day window in the logit and negative binomial specifications are negative but turn positive for windows thereafter. Thus, equity crowdfunding investors suffer from a default shock immediately after the event but recover fast after approximately 15 days.

In Fig. 2, we investigate the effects of experiencing an insolvency considering even longer time lags ranging from 3 to 28 days after the investor experienced an insolvency. 
Table 8 Regression results including ShareCapitalLost and ShareCapitalLost $\times$ Sustainability

\begin{tabular}{llll}
\hline Dependent variable & $(1)$ & $(2)$ & $(3)$ \\
& NewInvAmount & NewInvDummy & \#NewInv \\
\hline ShareCapitalLost & $70.9595^{* * *}$ & $0.0090^{* * *}$ & $0.6313^{* * * *}$ \\
& $(6.0143)$ & $(0.0749)$ & $(0.0498)$ \\
NumInsol & $-50.6663^{* * *}$ & $-0.0194 * * *$ & $0.7181^{* * *}$ \\
& $(4.0283)$ & $(0.0452)$ & $(0.0165)$ \\
Sustainability & $18.6670^{* * *}$ & $0.0270^{* * *}$ & $2.1581^{* * *}$ \\
& $(3.2140)$ & $(0.0305)$ & $(0.0094)$ \\
ShareCapitalLost $\times$ Sustainability & $-47.5715^{* * *}$ & $-0.0386^{* *}$ & $1.1516^{*}$ \\
& $(4.6040)$ & $(0.0452)$ & $(0.0826)$ \\
InvPast & $12.2718^{* * *}$ & $0.0062^{* * *}$ & $1.0674 * * *$ \\
ToP $\times 10^{-2}$ & $(0.7021)$ & $(0.0072)$ & $(0.0008)$ \\
Constant & $-6.4165^{* * *}$ & $-0.0068^{* * *}$ & $0.8732^{* * *}$ \\
Time FE & $(0.3431)$ & $(0.0063)$ & $(0.0011)$ \\
$\mathrm{N}$ & $62.5509^{* * *}$ & & $1.5671^{* * *}$ \\
Pseudo-/Adj. $\mathrm{R}^{2}$ & $(5.9267)$ & & $(0.0428)$ \\
$P(Y=1)$ & Yes & Yes & Yes \\
\hline
\end{tabular}

This table shows the results of the baseline regressions for the sampled dataset with $\mathrm{k}=3$ chosen nearest neighbors. We use the percentage of invested capital, which the investor lost from insolvencies, instead of the experienced insolvency dummy in this setting. In addition, we use the interaction term ExpInsol $\times$ Sustainability to check whether the reaction to experienced insolvencies changes if the investor is a sustainability-oriented investor rather than instead of a start-up investor. The dependent variable is the investor's newly invested amount (OLS, specification (1)), a dummy variable indicating whether the investor carried out at least one new investment in a certain campaign (logit, specification (2)), and the number of investments an investor newly undertook (negative binomial, specification (3)). Variables are defined in Table 1. Standard errors are clustered at the investor level and reported in parentheses. Coefficients reported are average marginal effects for the logit model and incidence rate ratios for the negative binomial model. Significance levels: $*<0.10, * *<0.05$, and $* * *<0.01$

The dotted lines show significant differences from an estimated coefficient to the estimated coefficients of the previous time lag. The figure reveals that the effect on investors' behavior after experiencing an insolvency varies over time. For the first 12 days after they experience an insolvency, the coefficient of ExpInsol is mostly significantly negative or close to zero, which evidences that investors invest less after experiencing a default. After this period, the coefficients are significantly positive, which indicates a recovery of the investors from the shock.

\subsection{Binomial test}

Our results suggest that except for the time immediately after an insolvency occurred in their portfolio, investors who experienced an insolvency generally make more investments after the event or only stop investing after they experience more than two insolvencies. In a next step, we investigate whether this behavior is consistent or inconsistent with investor expectations. On the one hand, crowd investors could invest more after they experienced an insolvency, because an insolvency could make the need for portfolio diversification more 
Table 9 Regression results including lagged variables of ExpInsol

\begin{tabular}{|c|c|c|c|}
\hline Dependent variable & $\begin{array}{l}\text { (1) } \\
\text { NewInvAmount }\end{array}$ & $\begin{array}{l}(2) \\
\text { NewInvDummy }\end{array}$ & $\begin{array}{l}\text { (3) } \\
\text { \#NewInv }\end{array}$ \\
\hline ExpInsol & $\begin{array}{l}56.7157 * * * \\
(5.7877)\end{array}$ & $\begin{array}{l}0.0481 * * * \\
(0.1036)\end{array}$ & $\begin{array}{l}2.0189 * * * \\
(0.0415)\end{array}$ \\
\hline NumInsol & $\begin{array}{l}-62.4449 * * * \\
(4.8490)\end{array}$ & $\begin{array}{l}-0.0312 * * * \\
(0.7927)\end{array}$ & $\begin{array}{l}0.5418 * * * \\
(0.0299)\end{array}$ \\
\hline ExpInsol_Lag ${ }_{1-5 \text { days }}$ & $\begin{array}{l}-43.2116^{* *} \\
(19.1655)\end{array}$ & & $\begin{array}{l}0.1925 * * \\
(0.7501)\end{array}$ \\
\hline ExpInsol_Lag $6-10$ days & $\begin{array}{l}10.6503 * * \\
(4.1860)\end{array}$ & $\begin{array}{l}-0.3241^{* * * *} \\
(0.5357)\end{array}$ & $\begin{array}{l}0.9082 \\
(0.0174)\end{array}$ \\
\hline ExpInsol_Lag ${ }_{11-15 \text { days }}$ & $\begin{array}{l}38.8940 * * * \\
(7.8207)\end{array}$ & $\begin{array}{l}0.1053 * * * \\
(0.1052)\end{array}$ & $\begin{array}{l}1.2350 * * * \\
(0.0629)\end{array}$ \\
\hline Sustainability & $\begin{array}{l}18.9251 * * * \\
(3.1618)\end{array}$ & $\begin{array}{l}0.0247 * * * \\
(0.0304)\end{array}$ & $\begin{array}{l}2.2050 * * * \\
(0.0092)\end{array}$ \\
\hline InvPast & $\begin{array}{l}11.8816^{* * * *} \\
(0.6441)\end{array}$ & $\begin{array}{l}0.0061 * * * \\
(0.0069)\end{array}$ & $\begin{array}{l}1.0722 * * * \\
(0.0007)\end{array}$ \\
\hline $\mathrm{ToP} \times 10^{-2}$ & $\begin{array}{l}-6.6900 * * * \\
(0.3275)\end{array}$ & $\begin{array}{l}-0.0071 * * * \\
(0.0061)\end{array}$ & $\begin{array}{l}0.8614 * * * \\
(0.0011)\end{array}$ \\
\hline Constant & $\begin{array}{l}63.7397 * * * \\
(5.9088)\end{array}$ & & $\begin{array}{l}1.5698 * * * \\
(0.0371)\end{array}$ \\
\hline Time FE & Yes & Yes & Yes \\
\hline $\mathrm{N}$ & 496,148 & 496,148 & 496,148 \\
\hline Pseudo-/Adj. R ${ }^{2}$ & 0.0122 & 0.1750 & 0.3257 \\
\hline$P(\mathrm{Y}=1)$ & & $7.11 \%$ & \\
\hline
\end{tabular}

This table shows the results of the baseline regressions for the sampled dataset with $k=3$ chosen nearest neighbors. We add three different lags with the length of seven days after an investor experienced the first insolvency to the model to catch whether a possible shock is temporary or not. The dependent variable is the investor's newly invested amount (OLS, specification (1)), a dummy variable indicating whether the investor carried out at least one new investment in a certain campaign (logit, specification (2)), and the number of investments an investor newly undertook (negative binomial, specification (3)). Variables are defined in Table 1. Standard errors are clustered at the investor level and reported in parentheses. Coefficients reported are average marginal effects for the logit model and incidence rate ratios for the negative binomial model. Significance levels: $*<0.10, * *<0.05$, and $* * *<0.01$

salient. On the other hand, they could have underestimated the risk of equity crowdfunding investments, and it would be logical for them to stop investing after experiencing one or more insolvencies.

To test the degree to which investor behavior in our sample is consistent or inconsistent with investor expectations, we compare the investor's realized default probability with an expected default probability. If the investor's realized default probability is higher than the expected default probability, the investor might reasonably update his or her ex ante beliefs about the expected default probability and stop investing in equity crowdfunding campaigns. If the investor's realized default probability is lower than the expected default probability, ceasing to invest could be a mistake and worsen the risk return profile of the portfolio. Because there is no true expected default probability in our setting, we need to use an approximation. The KfW-Gründungsmonitor analyzes the structure and development of German start-ups and estimates their survival rates for 1-36 months after funding with Kaplan-Meier estimations. 


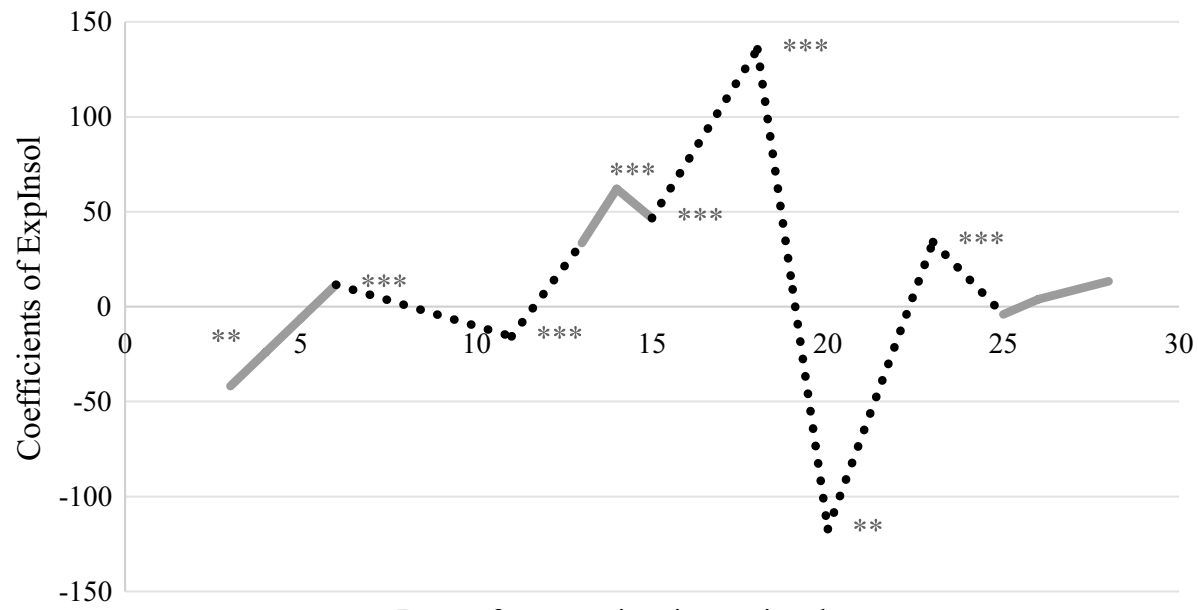

Days after experiencing an insolvency

Fig. 2 Lagged coefficients of ExpInsol. The figure shows the regression coefficients of ExpInsol dummy from our baseline regressions for the sampled dataset with $\mathrm{k}=3$ chosen nearest neighbors. Coefficients are estimated for different time lags ranging from 3 to 28 days after the investor experienced an insolvency. Dotted lines indicate significant differences from an estimated coefficient to the previous estimated coefficients. Significance levels: $*<0.10, * *<0.05$, and $* * *<0.01$

We adapt these probabilities as a proxy for the expected default probability in our sample. To calculate an investor's realized default probability, we divide the number of experienced insolvencies by the number of total investments made. We compare this probability with the expected default probability for the number of months the investor is active on the equity crowdfunding platform. For example, if an investor made the first investment 12 months ago, we choose as the expected default probability the Kaplan-Meier default probability from the $K f W$-Gründungsmonitor after 12 months. We use a binomial test to investigate whether the realized default probability is significantly higher or lower than the expected default probability, which helps us identify whether investors act in line with objective ex ante expectations.

We perform a one-sided binomial test to analyze whether the realized default probability is higher than the expected default probability. Figure 3 shows the distribution of the $p$-values for this conjecture for the 4559 investors who experienced at least one insolvency in our dataset. A small $p$-value of an investor indicates that the conjecture that the realized default probability is higher than the expected default probability can be rejected. In this case, ceasing to invest could be considered consistent with ex ante investor expectations. If we choose a $5 \%$ level of significance, we can reject the conjecture that the realized default probability is higher than the expected default probability for $47.7 \%$ of the investors, which implies that stopping to invest can be considered consistent with ex ante investor expectations. At the $1 \%$ level, only $35.4 \%$ of investors stop investing, while their realized default probability is higher than the expected default probability. At the $10 \%$ level, $55.4 \%$ of the investors act consistent with ex ante investor expectations.

In Table 10, we exclude investors who might rationally update their expectations from the analysis, because a significant proportion of investors could reasonably cease to diversify their portfolio if they conclude that the defaults they are experiencing are higher than what would have been expected based on a binomial test. We find that investors who act 


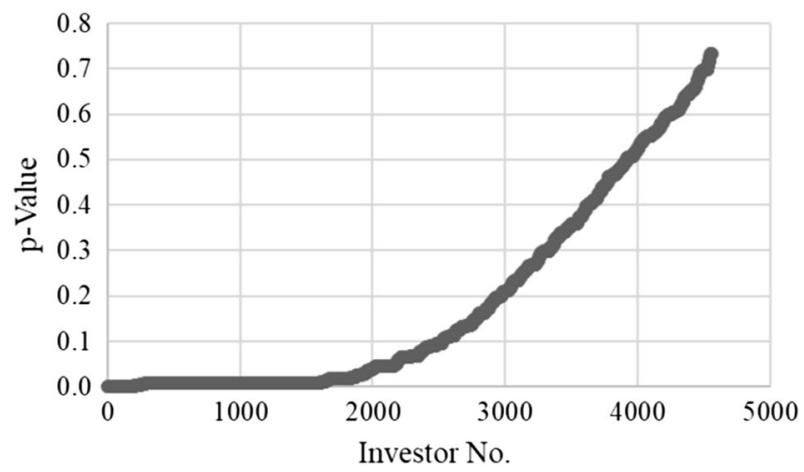

Fig. $3 P$-values for binomial test. The figure shows the distribution of $p$-values for binomial test with alternative hypothesis of higher realized default probability than expected default probability

Table 10 Regression results for all and irrational investors

\begin{tabular}{|c|c|c|c|c|}
\hline \multirow[b]{2}{*}{ Dependent variable } & \multicolumn{2}{|l|}{ All investors } & \multicolumn{2}{|c|}{ Irrational investors $(\alpha=0.1)$} \\
\hline & $\begin{array}{l}\text { (1) } \\
\text { NewInvAmount }\end{array}$ & $\begin{array}{l}\text { (2) } \\
\text { NewInvDummy }\end{array}$ & $\begin{array}{l}(3) \\
\text { NewInvAmount }\end{array}$ & $\begin{array}{l}\text { (4) } \\
\text { NewInvDummy }\end{array}$ \\
\hline ExpInsol & $\begin{array}{l}57.4821 * * * \\
(5.7675)\end{array}$ & $\begin{array}{l}0.0497 * * * \\
(0.1032)\end{array}$ & $\begin{array}{l}64.8152 * * * \\
(10.7072)\end{array}$ & $\begin{array}{l}0.0138 * * \\
(0.1251)\end{array}$ \\
\hline NumInsol & $\begin{array}{l}-62.5404 * * * \\
(4.8492)\end{array}$ & $\begin{array}{l}-0.0322 * * * \\
(0.0791)\end{array}$ & $\begin{array}{l}-77.0512 * * * \\
(8.7026)\end{array}$ & $\begin{array}{l}-0.0263 * * * \\
(0.0877)\end{array}$ \\
\hline Sustainability & $\begin{array}{l}18.9120 \\
(3.1624)\end{array}$ & $\begin{array}{l}0.0280 * * * \\
(0.0304)\end{array}$ & $\begin{array}{l}70.2913^{*} \\
(12.5345)\end{array}$ & $\begin{array}{l}0.0978 * * * \\
(0.8094)\end{array}$ \\
\hline InvPast & $\begin{array}{l}11.8736 * * * \\
(0.6437)\end{array}$ & $\begin{array}{l}0.0063 * * * \\
(0.0069)\end{array}$ & $\begin{array}{l}11.0012 * * * \\
(0.8552)\end{array}$ & $\begin{array}{l}0.0057 * * * \\
(0.0078)\end{array}$ \\
\hline $\mathrm{ToP} \times 10^{-2}$ & $\begin{array}{l}-6.6871^{* * * *} \\
(0.3275)\end{array}$ & $\begin{array}{l}-0.0072 * * * \\
(0.0061)\end{array}$ & $\begin{array}{l}-4.7938 * * * \\
(0.7064)\end{array}$ & $\begin{array}{l}-0.0073^{* * * *} \\
(0.0114)\end{array}$ \\
\hline Constant & $\begin{array}{l}63.6191 * * * \\
(5.9077)\end{array}$ & & $\begin{array}{l}76.0806^{* * * *} \\
(11.8728)\end{array}$ & \\
\hline Time FE & Yes & Yes & Yes & Yes \\
\hline $\mathrm{N}$ & 496,148 & 496,148 & 133,891 & 133,891 \\
\hline Pseudo-/Adj. $\mathrm{R}^{2}$ & 0.0119 & 0.1719 & 0.0170 & 0.2260 \\
\hline$P(\mathrm{Y}=1)$ & & $7.11 \%$ & & $9.8939 \%$ \\
\hline
\end{tabular}

This table shows the regression results for the investment behavior with varying definition of rationally updating investors. In columns 1 and 2, we consider all investors in our sampled dataset. We exclude investors who may rationally conclude from an experienced insolvency that their realized probability for experiencing insolvencies is higher than expected in columns 3 and 4, which is based on a binomial test with a significance level of $10 \%$. The dependent variable is the investor's newly invested amount (OLS, specification (1)) and a dummy variable indicating whether the investor carried out at least one new investment in a certain campaign (logit, specification (2)). Variables are defined in Table 1. Standard errors are clustered at the investor level and reported in parentheses. Coefficients reported are average marginal effects for the logit model. Significance levels: $*<0.10, * *<0.05$, and $* * *<0.01$

irrational are more affected by a default shock, because the coefficient of ExpInsol is significant lower (difference in coefficients, $p<0.001$ ) for those investors in the logit regression (Column (2) vs. (4)). However, irrational investors invest higher amounts, because 
the coefficient of ExpInsol increases when we exclude rational investors from the analysis. In both models, we find significantly higher coefficients for Sustainability when only irrational investors remain, which implies that investors who irrationally respond to a default shock invest more often and higher amounts in sustainability-oriented campaigns than other investors.

\subsection{Additional robustness checks}

We run several robustness tests to our analyses. In Table OA1 in the Online Appendix, the variable AltPlatform captures the number of investment opportunities on the respective equity crowdfunding platform on which the investor is active and AltGlobal captures the investment opportunities in the entire equity crowdfunding market in Germany. We find that the probability to invest in a certain campaign on the platform decreases when more investment opportunities are available on the platform. However, in line with Dorfleitner et al. (2019), the probability of an investment increases when there are more active campaigns in the entire German equity crowdfunding market. Furthermore, we find evidence of a non-linear relationship between the time on the platform and the decision to invest on that platform (see Table OA2 in the Online Appendix).

In Table OA3 of the Online Appendix, we include the interaction term ExpInsol $\times$ InvPast to test whether more experienced investors react differently after experiencing an insolvency. We find that more experienced investors are less likely to continue investing after an insolvency. In Table OA4 of the Online Appendix, we consider AmountLost instead of Share CapitalLost as an additional robustness check and interact it with ExpInsol to examine whether there is a stronger default shock when the investor lost a larger amount of money. Similar to Dorfleitner et al. (2019), we compute ExpInsol30 as a dummy variable for the default shock in Tables OA5 and OA6 of the Online Appendix, which switches to 1 only if the investor experienced at least one insolvency in the last 30 days. Our results remain robust to these alternative specifications.

We provide six additional robustness checks to ensure the validity of our results. First, we run the same regression models over the full sample of available data without matching (Tables OA7-OA10 in the Online Appendix). On the one hand, even if techniques such as the KNN sampling generally improve statistical inference, it is still possible that use of this sampling procedure overlooks important observations, which could cause an estimation bias. On the other hand, similarity of results from the full sample to the results from the matched sample can be a validation of the results, but should not be expected. In the full sample analysis, our data contain 1,249,271 investment decisions by 26,241 investors. Overall, 4559 investors experienced at least one insolvency, while 21,682 investors did not experience any insolvency. The results from the full sample analysis hardly differ from our previous results with regard to the variables of interest. In Table OA7 in the Online Appendix, the coefficient of Sustainability is now also significant and positive in the OLS regression. Moreover, in Table OA10 in the Online Appendix, the incident rate ratio for Share CapitalLost is now greater than 1 and the incident rate ratio of Share CapitalLost $\times$ Sustainability is less than 1 .

Second, we repeat our sampling procedure and chose $\mathrm{k}=1$ nearest neighbor (Tables OA11-OA14 in the Online Appendix). This results in 370,696 investment decisions by 7044 investors, 4559 of whom experienced at least one insolvency and 2485 zero insolvencies. Again, we delete the "non-insolvency" investors from the control group, who were matched by the KNN procedure with multiply "insolvency" treatment group investors, 
which results in an unequal number of observations in both groups. The results with only $\mathrm{k}=1$ nearest neighbor do not differ in terms of the signs of our variables of interest from the results with $k=3$ chosen nearest neighbors. In Table OA12, the coefficient of ExpInsol $\times$ Sustainability in the logit specification and the coefficient of ShareCapitalLost in Table OA14 become non-significant.

Third, we use Mahalanobis distance matching instead of Euclidean distance matching (King \& Nielsen, 2019) and find similar results. Fourth, we repeat the binomial test, taking into account that Home Rocket is a platform from Austria and default probabilities might differ from Germany. We therefore use expected default rates for Austrian start-ups published by the Kreditschutzverband von 1870 and apply a 5\% level of significance. The default probabilities of Austrian companies are similar to those of German companies, which is why the results of the binomial test are also similar. We now reject our conjecture that the realized default probability is higher than the expected default probability for $41 \%$ of the investors (vs. 47\% using expected default rates from German start-ups).

Finally, an argument could be made that crowd investors who invest on a greater number of equity crowdfunding platforms are also more likely to invest in more campaigns and invest less after they lose money. In unreported regressions, we find that investors who are active on multiple platforms are generally more likely to invest in an equity crowdfunding campaign. Moreover, they are also more affected by a default shock, because they invest less often and smaller amounts after an insolvency occurred in their equity crowdfunding portfolio. We find very similar results when we restrict our sample to investors from Green Rocket, Home Rocket, and Lion Rocket. In this subsample analysis, the coefficient of ExpInsol is significantly negatively associated with our dependent variables, while the other results remain largely unaffected.

\section{Discussion}

It might be argued that the variable Sustainability is a placeholder for investments of crowd investors who are less likely to be purely motivated by financial reasons. Until now, three archetypes of investment platforms have emerged in the equity crowdfunding market: (1) equity crowdfunding platforms that predominantly fund start-up firms, (2) real estate crowdfunding platforms that fund real estate campaigns, and (3) sustainability-oriented platforms that fund sustainability-oriented campaigns. It is not clear, whether equity and real estate crowdfunding platforms also include sustainability-oriented campaigns. For example, start-ups might invent new business models in the bio-based economy, or real estate campaigns might ecologically reconstruct existing buildings. To test whether campaigns brokered on sustainability-oriented platforms were indeed more appealing to sustainability-oriented investors, we presented original investment descriptions of the crowdfunding campaigns to 72 German individuals on the crowdsourcing platform Amazon Mechanical Turk (MTurk) who were unrelated to our study. We asked them to rate ten randomly selected campaigns (ten-point Likert scale) with two questions: How much would the described campaign appeal to a sustainability-oriented investor? and How much would the described campaign appeal to a purely return-oriented investor? The MTurkers received no information about whether the campaign was brokered on a sustainabilityoriented platform or not.

We found that descriptions of campaigns listed on sustainability-oriented platforms were rated 33\% more appealing, on average, to sustainability-oriented investors than campaigns 
on ordinary crowdfunding platforms $(p<0.001)$. According to Hudson's (2005) theoretical analysis, sustainability-oriented equity crowdfunding campaigns should pay the same returns as ordinary, purely return-oriented equity crowdfunding campaigns. Our MTurk survey indicates that sustainability-oriented campaigns are indeed not more or less appealing to ordinary, purely return-oriented crowd investors, as the $3.5 \%$ difference in the appeal of campaigns to purely return-oriented investor is not significant $(p=0.204)$. This indirect evidence indicates that campaigns on all three types of platforms should pay a market return.

Investors of SRI-profiled mutual funds often combine SEE motives with traditional investment objectives (McCann et al., 2003; Michelson et al., 2004; Nilsson, 2008; Sparkes, 2002). Examination of surveys and blog entries on investor behavior in equity crowdfunding indicates that investors on return-oriented platforms indeed have more return-oriented preferences (Seedmatch, 2013), while investors on sustainability-oriented platforms more often have sustainability-oriented preferences (Aktiendepot, 2020; Biallo, 2019; Geldbewegt, 2020). A survey on investment decisions of 300 crowd investors on Seedmatch (2013), which focuses on equity crowdfunding for start-ups, revealed that $89 \%$ of investors consider it important to generate a positive return. An interview with Astrid Vancraeyenest from the SEE-oriented platform Bettervest emphasizes that sustainability, in addition to return on investment, is an important factor for many crowd investors on Bettervest (Biallo, 2019). Taking these findings into account, we do not argue that investors on Bettervest and Green Rocket are only sustainability oriented while investors on the other platforms are purely return oriented. Investors on sustainability-oriented platforms also most likely expect to be compensated for market risk (Hudson, 2005) and to earn a respective return, which is in line with our MTurk survey. The question that arises is whether such mixed motives affect our empirical estimates, as our theoretical concepts suffer empirically from measurement error. Certainly, the variable Sustainability does not capture the full effect of purely sustainability-oriented investors, because investors on sustainability-oriented platforms have financial motives as well. Thus, we underestimate the true coefficients that would be obtained if sustainability-oriented investors had no financial motives at all. In other words, our results are lower bounds and thus conservative empirical estimates.

Dorfleitner et al. (2019) show not only that investors change their behavior after an insolvency but also that this behavior is irrational. That is, lenders in crowdlending are shocked by an insolvency and reduce their investment amounts and the number of investments; however, this behavior negatively affects their risk return profile. We cannot test this conjecture in a similar manner in our setting, because unlike in crowdlending, repayments to investors in equity crowdfunding often take several years. This makes it barely possible to calculate the RAROC for the investment period under consideration. However, we find some first evidence that investment behavior of equity crowdfunding investors is in many cases inconsistent with rational ex ante expectations about default probabilities. Using a binomial test, we show that a substantial fraction of investors changes their investment behavior after an insolvency, even though the insolvencies they experienced are in line with what would have been expected by a rational investor.

A notable finding from our data is that investors generally tend to invest more and not less after experiencing an insolvency. At first glance, this result is in contrast with Dorfleitner et al. (2019), who investigate lenders on a crowdlending platform. One explanation for this finding could be that investors who invest more are generally also more likely to experience an insolvency and our result is due to reverse causality. This explanation, however, is unlikely to be true given that we use a matched control group of investors with similar experience in equity crowdfunding, number of investments, and total investment amounts. Another explanation could be that investors in equity crowdfunding behave somewhat 
differently from lenders in a crowdlending context. Equity crowdfunding differs from crowdlending, for example, in that repayments in crowdlending begin immediately after funding, while in equity crowdfunding, repayments normally take several years. Investors in equity crowdfunding thus observe cash flows less frequently and therefore might also be less engaged after the funding has ended. Finally, our findings indicate that the positive default shock turns negative immediately after the event or if investors experience more than two insolvencies. Experiencing more than two insolvencies is not unlikely to happen given that $30 \%$ of crowd funded firms in Germany fail three years after funding (Hornuf et al., 2018b). Our results are thus not that different from Dorfleitner et al.'s (2019).

\section{Conclusion}

Our findings extend previous research in at least three ways. First, we contribute to the literature on how sustainability-oriented investors allocate their portfolio holdings (Heeb et al., 2021; Mackenzie \& Lewis, 1999; Siemroth \& Hornuf, 2021; Webley et al., 2001). The results of our multivariate analyses indicate that sustainability-oriented investors pledge larger amounts and invest in more campaigns. Second, while Dorfleitner et al. (2019) investigate only investors who have pledged money in company loans, we differentiate between investors who made investments in ordinary start-up firms and those who made investments in sustainability-oriented firms. Given that sustainability-oriented investors have investment motives other than a pure financial return motive, we would expect them to be shocked even more severely if they experience a default in their equity crowdfunding portfolio. Our results are in line with the notion that sustainability-oriented investors care about non-financial returns, as they react more negatively when experiencing a default in their portfolio, which indicates that they suffer beyond the pure financial loss. Third, we also provide external validity for the default shock that Dorfleitner et al. (2019) identify by extending the evidence to a new market segment and six different platforms. Our findings are more nuanced: We find evidence of a default shock, but only immediately after an insolvency took place. The default shock disappears two weeks after the insolvency took place and makes investments by those that experienced a default again more likely. Moreover, we find that a default shock generally exists in equity crowdfunding if investors experience more than two insolvencies.

Our findings also yield new insights into how personal experience affects investment decisions. We find that the experience of a default changes the willingness to make new investments, but this effect depends on the respective investor type. This also has implications for the regulation of new asset classes, such as equity crowdfunding, and how to protect investors. Some investors might engage with these new markets for the sole purpose of generating a financial return, while others might consider personal values and societal concerns when making an investment. Investors' interests might even be more severely harmed if, in addition to their financial loss, their personal values and societal concerns are violated because a crowdfunding campaign fails. Platform managers who are aware of the default shock bias should in particular encourage sustainability-oriented investors to continue investing after they have experienced an insolvency, because doing so will most likely help investors to improve the risk return profile of their portfolio. Moreover, equity crowdfunding regulation generally does not take personal values and investment motives into account (Goethner et al., 2021). Our research shows that setting simple investment limits to protect retail investors might be misleading and that investor protection might need to take individual investment motives such as the sustainability orientation into account. 
Our research has clear limitations and offers avenues for further research at the same time. The equity crowdfunding portfolios we investigate in our empirical analysis are only a subset of the overall investor portfolio, which might, for example, include ordinary stocks, fixed income products, mutual funds, or commodities. While we are interested in how an insolvency of an equity crowdfunding issuer affects investor behavior in equity crowdfunding, it would be useful to know how defaults in the overall portfolio affect investor behavior in equity crowdfunding and vice versa. Future research might be able to merge data from equity crowdfunding with overall investor holdings and conduct such analyses. Furthermore, while this type of information is not necessary to answer our research question, it would be interesting to learn more about the investors who are active on different equity crowdfunding platforms. For example, what is their gender? Where do they come from? How financially experienced are they? A natural research question future studies might answer is whether socio-demographic variables affect the decision to make socially responsible investments in equity crowdfunding and whether these variables influence investment behavior. Finally, unlike Dorfleitner et al. (2019), we are not able to calculate the RAROC for the portfolios of our crowd investors. This will be possible in four to five years, after investors have received sufficient repayments from their investment targets. Calculating the RAROC and identifying the investors who stopped investing after realizing the default probability in their portfolio was smaller than the expected default probability would allow us to judge whether the default shock in equity crowdfunding constitutes a bias or not.

Supplementary Information The online version contains supplementary material available at https://doi. org/10.1007/s10961-021-09896-9.

Acknowledgements The authors thank Daniel Blaseg, Engin Iyidogan, Spyros Terovitis, Silvio Vismara, two anonymous referees, and the participants of the 7th Crowdinvesting Symposium at HU Berlin (8th November 2019, Berlin) for their thoughtful comments and suggestions.

Funding Open Access funding enabled and organized by Projekt DEAL.

Open Access This article is licensed under a Creative Commons Attribution 4.0 International License, which permits use, sharing, adaptation, distribution and reproduction in any medium or format, as long as you give appropriate credit to the original author(s) and the source, provide a link to the Creative Commons licence, and indicate if changes were made. The images or other third party material in this article are included in the article's Creative Commons licence, unless indicated otherwise in a credit line to the material. If material is not included in the article's Creative Commons licence and your intended use is not permitted by statutory regulation or exceeds the permitted use, you will need to obtain permission directly from the copyright holder. To view a copy of this licence, visit http://creativecommons.org/licenses/by/4.0/.

\section{References}

Agrawal, A., Catalini, C., \& Goldfarb, A. (2016). Are syndicates the killer app of equity crowdfunding? California Management Review, 58(2), 111-124.

Ahlers, G. K., Cumming, D., Günther, C., \& Schweizer, D. (2015). Signaling in equity crowdfunding. Entrepreneurship Theory and Practice, 39(4), 955-980.

Aktiendepot. (2020). Nachhaltiges Invest mit Crowdinvesting - Über Crowdinvesting nachhaltige Projekte finanzieren!. Retrieved from https://www.aktiendepot.com/nachhaltiges-invest-mit-crowdinvesting/ " $\backslash 1$ "fazit-mit-crowdinvesting-nachhaltig-investieren-zahlt-sich-fur-alle-beteiligten-aus. Last accessed 12 May 2020.

Andersen, S., Hanspal, T., \& Nielsen, K. M. (2019). Once bitten, twice shy: The power of personal experiences in risk taking. Journal of Financial Economics, 132(2), 97-117. 
Beal, D., \& Goyen, M. (1998). Putting your money where your mouth is: A profile of ethical investors. Financial Services Review, 7(2), 129-144.

Beal, D. J., Goyen, M., \& Philips, P. (2005). Why do we invest ethically? Journal of Investing, 14(3), 66-77.

Belleflamme, P., Lambert, T., \& Schwienbacher, A. (2014). Crowdfunding: Tapping the right crowd. The Journal of Business Venturing, 29(5), 585-609.

Berger, I. E., \& Corbin, M. R. (1992). Perceived consumer effectiveness and faith in others as moderators of environmentally responsible behaviors. Journal of Public Policy \& Marketing, 11(2), 79-100.

Biallo. (2019). Nachhaltiges Crowdinvesting: Mehr als nur gute Rendite. Retrieved from https://www.biallo. de/geldanlage/ratgeber/nachhaltiges-crowdinvesting. Last accessed 12 May 2020.

Block, J., Colombo, M. G., Cumming, D. J., \& Vismara, S. (2018a). New players in entrepreneurial finance and why they are there. Small Business Economics, 50(2), 239-250.

Block, J., Hornuf, L., \& Moritz, A. (2018b). Which updates during an equity crowdfunding campaign increase crowd participation? Small Business Economics, 50(1), 3-27.

Bollen, N. P. B. (2007). Mutual fund attributes and investor behavior. Journal of Financial and Quantitative Analysis, 42(3), 683-708.

Butticè, V., Di Pietro, F., \& Tenca, F. (2021). They do not look alike: What kind of private investors do equity crowdfunded firms attract? The Journal of Technology Transfer (forthcoming).

Byrne, K. (2005). How do consumers evaluate risk in financial products? Journal of Financial Services Marketing, 10(1), 21-36.

Calic, G., \& Mosakowski, E. (2016). Kicking off social entrepreneurship: How a sustainability orientation influences crowdfunding success. Journal of Management Studies, 53(5), 738-767.

Chiang, Y. M., Hirshleifer, D., Qian, Y., \& Sherman, A. E. (2011). Do investors learn from experience? Evidence from frequent IPO investors. Rev. Financ. Stud., 24(5), 1560-1589.

Choi, J. J., Laibson, D., Madrian, B. C., \& Metrick, A. (2009). Reinforcement learning and savings behavior. The Journal of Finance, 64(6), 2515-2534.

Cholakova, M., \& Clarysse, B. (2015). Does the possibility to make equity investments in crowdfunding projects crowd out reward-based investments? Entrepreneurship Theory and Practice, 39(1), 145-172.

Coakley, J. (2021). Strategic entrepreneurial choice between competing crowdfunding platforms. The Journal of Technology Transfer (forthcoming).

Cullis, J. G., Lewis, A., \& Winnett, A. (1992). Paying to be good: UK ethical investments. Kyoklos, 45(1), $3-24$.

Dorfleitner, G., Hornuf, L., \& Weber, M. (2019). Paralyzed by shock: The portfolio formation behavior of peer-to-business lending investors. CESifo working papers 7092.

Ellen, P. S., Wiener, J. L., \& Cobb-Walgren, C. (1991). The role of perceived consumer effectiveness in motivating environmentally conscious behaviors. Journal of Public Policy \& Marketing, 10(2), 102-117.

Freear, J., Sohl, J. E., \& Wetzel, W. E., Jr. (1994). Angels and non-angels: Are there differences? The Journal of Business Venturing, 9(2), 109-123.

Geld-bewegt. (2020). Nachhaltig investieren mit der Crowd? Retrieved from https://www.geld-bewegt.de/ wissen/geld-versicherungen/nachhaltige-geldanlage/nachhaltig-investieren-mit-der-crowd-16773. Last accessed 12 May 2020.

Gevlin, K. (2007). The coming of age of socially responsible investing. Financial Planning, 37(8), 56.

Goethner, M., Hornuf, L., \& Regner, T. (2021). Protecting investors in equity crowdfunding: An empirical analysis of the small investor protection act. Technological Forecasting and Social Change, 162, 120352.

Günther, C., Johan, S., \& Schweizer, D. (2018). Is the crowd sensitive to distance? How investment decisions differ by investor type. Small Business Economics, 50(2), 289-305.

Hainz, C., \& Hornuf, L. (2019). Praxiserfahrungen mit den Befreiungsvorschriften des Kleinanlegerschutzgesetzes: Eine aktuelle Bestandsaufnahme. ifo Forschungsberichte 102, Munich, ifo Institute.

Hainz, C., Hornuf, L., Nagel, L., Reiter, S., \& Stenzhorn, E. (2019). Exemption provisions of the German small investor protection act: A follow-up study. ifo DICE Report, 17(2), 41-51.

Heeb, F., Kölbel, J., Paetzold, F., \& Zeisberger, S. (2021). Do investors care about impact? SSRN Working Paper. Retrieved from https://ssrn.com/abstract=3765659. Last accessed 10 March 2021.

Hörisch, J. (2015). Crowdfunding for environmental ventures: An empirical analysis of the influence of environmental orientation on the success of crowdfunding initiatives. Journal of Cleaner Production, 107, 636-645.

Hornuf, L., Schmitt, M., \& Stenzhorn, E. (2020). Does a local bias exist in equity crowdfunding? Max Planck Institute for Innovation \& Competition Research Paper No. 16-07.

Hornuf, L., Schilling, T., \& Schwienbacher, A. (2021). The relevance of investor rights in crowdinvesting. Journal of Corporate Finance (forthcoming).

Hornuf, L., Klöhn, L., \& Schilling, T. (2018a). Financial contracting in crowdinvesting-lessons from the German market. German Law Journal, 19(3), 509-578. 
Hornuf, L., Schmitt, M., \& Stenzhorn, E. (2018b). Equity crowdfunding in Germany and the United Kingdom: Follow-up funding and firm failure. Corp. Gov. Int. Rev., 26(5), 331-354.

Hornuf, L., \& Schwienbacher, A. (2018a). Internet-based entrepreneurial finance: Lessons from Germany. California Management Review, 60(2), 150-175.

Hornuf, L., \& Schwienbacher, A. (2018b). Market mechanisms and funding dynamics in equity crowdfunding. Journal of Corporate Finance, 50, 556-574.

Hudson, R. (2005). Ethical investing: Ethical investors and managers. J. Ethics q., 15(4), 641-657.

Hummels, H., \& Timmer, D. (2004). Investors in need of social, ethical, and environmental information. Journal of Business Ethics, 52(1), 73-84.

Jansson, M., \& Biel, A. (2011). Motives to engage in sustainable investment: A comparison between institutional and private investors. Sustainable Development, 19, 135-142.

Johan, S., \& Zhang, Y. (2021). Investors' industry preference in equity crowdfunding. The Journal of Technology Transfer (forthcoming).

Kahnemann, D., \& Tversky, A. (1979). Prospect theory: An analysis of decision under risk. In L. MacLean \& W. T. Ziemba (Eds.), Handbook of the fundamentals of financial decision making. London: World Scientific. https://doi.org/10.1142/8557

Kaustia, M., \& Knüpfer, S. (2008). Do investors overweight personal experience? Evidence from IPO subscriptions. The Journal of Finance, 63(6), 2679-2702.

King, G., \& Nielsen, R. (2019). Why propensity scores should not be used for matching. Political Analysis, 27(4), 435-454.

Kleinert, S., \& Volkmann, C. (2019). Equity crowdfunding and the role of investor discussion boards. Venture Capital, 21(4), 327-352.

Knüpfer, S., Rantapuska, E., \& Sarvimäki, M. (2017). Formative experiences and portfolio choice: Evidence from the Finnish great depression. The Journal of Finance, 72(1), 133-166. https://doi.org/10. 1111/jofi.12469

Lagerkvist, C. J., Edenbrandt, A. K., Tibbelin, I., \& Wahlstedt, Y. (2020). Preferences for sustainable and responsible equity funds: A choice experiment with Swedish private investors. Journal of Behavioral and Experimental Finance, 28, 100406. https://doi.org/10.1016/j.bef.2020.100406

Laudenbach, C., Loos, B., \& Pirschel, J. (2017). Recent experiences and risk taking: Trading responses to changes in the local environment. Working Paper.

Levitt, S. D., \& List, J. A. (2007). What do laboratory experiments measuring social preferences reveal about the real world? JEP, 21(2), 153-174.

Lewis, A., \& Mackenzie, C. (2000). Morals, motives and money: the case of U.K. ethical investing. Human Relations, 53(2), 179-191.

Lewis, A., \& Mackenzie, C. (2000b). Support for investor activism among UK ethical investors. Journal of Business Ethics, 24(3), 215-222.

Lewis, A., \& Webley, P. (1994). Social and ethical investing. In A. Lewis \& K.-E. Wärneryd (Eds.), Ethics and economic affairs (pp. 171-182). Routledge.

Lukkarinen, A., \& Schwienbacher, A. (2021). Secondary market listings in equity crowdfunding: The missing link? SSRN Working Paper. Retrieved from https://ssrn.com/abstract=3725498. Last accessed 27 June 2021.

MacGregor, D., Slovic, P., Berry, M., \& Evenski, H. R. (1999). Perception of financial risk: A survey study of advisors and planners. Journal of Financial Planning, 12(8), 68-86.

Mackenzie, C., \& Lewis, A. (1999). Morals and markets: The case of ethical investing. Business Ethics Quarterly, 9(3), 439-452.

Malmendier, U., \& Nagel, S. (2011). Depression babies: Do macroeconomic experiences affect risk taking? The Quarterly Journal of Economics, 126(1), 373-416.

Marsat, S., Pijourlet, G., \& Williams, B. (2018). Disentangling financial and ethical effects of corporate social responsibility on firm value. In S. Boubaker, D. Cumming, \& D. K. Nguyen (Eds.), Research handbook of finance and sustainability (pp. 72-92). Edward Elgar Publishing Inc.

McCann, L., Solomon, A., \& Solomon, J. F. (2003). Explaining the growth in UK socially responsible investment. Journal of General Management, 28(4), 15-36.

McLachlan, J., \& Gardner, J. (2004). A comparison of socially responsible and conventional investors. Journal of Business Ethics, 52(1), 11-25.

Michelson, G., Wailes, N., van der Laan, S., \& Frost, G. (2004). Ethical investment processes and outcomes. Journal of Business Ethics, 52(1), 1-10.

Nguyen, T., Cox, J., \& Rich, J. (2019). Invest or regret? An empirical investigation into funding dynamics during the final days of equity crowdfunding campaigns. Journal of Corporate Finance, 58, 784-803. 
Nilsson, J. (2008). Investment with a conscience: Examining the impact of pro-social attitudes and perceived financial performance on socially responsible investment behavior. Journal of Business Ethics, $83,307-325$.

Owen, A., \& Qian, Y. (2008). Determinants of socially responsible investment decisions. Empirical Economics Letters. Hamilton College Sustainability Working Paper \#2008-2 (pp. 1-10).

Palacios-González, M. M., \& Chamorro-Mera, A. (2018). Analysis of the predictive variables of the intention to invest in a socially responsible manner. Journal of Cleaner Production, 196, 469-477.

Pasewark, W. R., \& Riley, M. E. (2010). It's a matter of principle: The role of personal values in investment decisions. Journal of Business Ethics, 93, 237-253.

Peifer, J. L. (2014). Fund loyalty among socially responsible investors: The importance of the economic and ethical domains. Journal of Business Ethics, 121, 635-649.

Ramos, J. (2014). Crowdfunding and the role of managers in ensuring the sustainability of crowdfunding platforms. In J. Stewart (Ed.), JRC technical report series. JRC Institute for Prospective Technological Studies, European Commission. Retrieved from ftp://ftp.jrc.es/pub/EURdoc/JRC85752.pdf. Last accessed 15 Dec 2019.

Riedl, A., \& Smeets, P. (2017). Why do investors hold socially responsible mutual funds? The Journal of Finance, 72(6), 2505-2550.

Rivoli, P. (2003). Making a difference or making a statement? Finance research and socially responsible investment. Business Ethics Quarterly, 13(3), 271-287.

Rosen, B. N., Sandler, D. M., \& Shani, D. (1991). Social issues and socially responsible investment behavior: A preliminary empirical investigation. Journal of Consumer Affairs, 25(3), 221-234.

Sandberg, J. (2018). Towards a theory of sustainable finance. In T. Walker, S. D. Kibsey, \& R. Crichton (Eds.), Designing a sustainable financial system: Development goals and socio-ecological responsibility (p. 11). Springer.

Seedmatch. (2013). Investoren-Survey: Analysieren Sie noch oder investieren Sie schon? Retrieved from https://blog.seedmatch.de/investoren-survey-analysieren-sie-noch-oder-investieren-sie-schon/. Last accessed 12 May 2020.

Siemroth, C., \& Hornuf, L. (2021). Does environmental impact matter to retail investors? A lab-in-thefield experiment with crowdfunders. CESifo Working Paper No. 9197. Retrieved 13 October 2021 from https://ssrn.com/abstract=3892621.

Signori, A., \& Vismara, S. (2018). Does success bring success? The post-offering lives of equity-crowdfunded firms. Journal of Corporate Finance, 50, 575-591.

Social Investment Forum. (2008). Retrieved from http://invest.org/news/releases/pressrelease.cfm?id=108. Last accessed 18 April 2020.

Sparkes, R. (2001). Ethical investment: Whose ethics, which investment? Business Ethics: A European Review, 10(3), 194-205.

Sparkes, R. (2002). Socially responsible investment: A global revolution. Wiley.

Statman, M. (2000). Socially responsible mutual funds. Financial Analysts Journal, 56(3), 30-39.

Straughan, R., \& Roberts, J. (1999). Environmental segmentation alternatives: A look at green consumer behavior in the new millennium. Journal of Consumer Marketing, 16(6), 558-575.

Vismara, S. (2016). Equity retention and social network theory in equity crowdfunding. Small Business Economics, 46(4), 579-590.

Vismara, S. (2018). Signaling to overcome inefficiencies in crowdfunding markets. In D. Cumming \& L. Hornuf (Eds.), The economics of crowdfunding (pp. 29-56). Palgrave Macmillan.

Vismara, S. (2019). Sustainability in equity crowdfunding. Technological Forecasting and Social Change, $141,98-106$.

Vulkan, N., Åstebro, T., \& Sierra, M. F. (2016). Equity crowdfunding: A new phenomena. Journal of Business Venturing Insights, 5, 37-49.

Webley, P., Lewis, A., \& Mackenzie, C. (2001). Commitment among ethical investors: An experimental approach. Journal of Economic Psychology, 22(1), 27-42.

Williams, G. (2007). Some determinants of the socially responsible investment decision: A cross-country study. Journal of Behavioral Finance, 8(1), 43-57.

Wins, A., \& Zwergel, B. (2016). Comparing those who do, might and will not invest in sustainable funds: A survey among German retail fund investors. Business Research, 9, 51-99.

Publisher's Note Springer Nature remains neutral with regard to jurisdictional claims in published maps and institutional affiliations. 